\title{
Pan, God of Wilderness, in Boeotian Landscapes: Fear, Laughter and Coming of Age
}

Pan, divinità del mondo selvaggio nel paesaggio beotico: paura, risata rituale e riti di passaggio

\section{Victoria Sabetai}

\section{OpenEdition}

\section{Journals}

\section{Electronic version}

URL: https://journals.openedition.org/mythos/1379

DOI: $10.4000 /$ mythos.1379

ISSN: 2037-7746

\section{Publisher}

Salvatore Sciascia Editore

Electronic reference

Victoria Sabetai, "Pan, God of Wilderness, in Boeotian Landscapes: Fear, Laughter and Coming of Age", Mythos [Online], 13 | 2019, Online since 17 November 2019, connection on 21 September 2021. URL: http://journals.openedition.org/mythos/1379 ; DOl: https://doi.org/10.4000/mythos.1379

This text was automatically generated on 21 September 2021.

Mythos 


\section{Pan, God of Wilderness, in Boeotian Landscapes: Fear, Laughter and Coming of Age}

Pan, divinità del mondo selvaggio nel paesaggio beotico: paura, risata rituale e riti di passaggio

Victoria Sabetai

I thank warmly V. Zachari and Th. Galoppin for their invitation to the inspiring seminar "Into the Wild. Chercher les puissances divines hors les murs" at the EHESS, Paris (23.7.2018) where this paper was conceived and for their useful suggestions. For photographs of objects in their ephorate and/or museum collections I am grateful to V. Vassilopoulou, N. Skoumi, R. Splitter and N. Massar. I also thank M. Markantonatos for her assistance. In this paper Pan's presence in Boeotian cult and art of the $5^{\text {th }}$ and $4^{\text {th }}$ c. BC is briefly outlined.

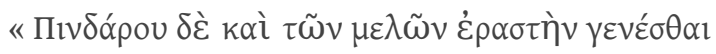

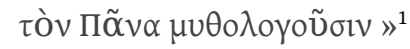

\section{Introduction : Divinising the Goat, Humanizing the Goat-god}

1 Son of Hermes and a nymph, Pan was the quintessential god of wild nature and an interstitial divinity in the form of a hybrid with caprine and human characteristics. ${ }^{2} \mathrm{His}$ sphere of activity was the uncultivated land extending beyond the poleis and their chora. The wilderness was not merely a geographical area for the ancients, but a space with an impact on cultural imagination. It was often perceived as the opposite of the civilized realm of the city, ${ }^{3}$ a primitive and potentially dangerous territory with immanent divine powers. ${ }^{4}$ On a metaphorical level it served as a vehicle for Greek concepts of liminality which were often associated with transitional phases of human life and were imbued with feelings of anxiety and fear. 
2 Among the various deities populating the wilds, the Nymphs and Pan were the most universally known and venerated despite their lowly position in the hierarchy of the Greek pantheon. Both were associated with vegetation and undomesticated animal life as well as with humans seeking their divine protection at moments of transition. ${ }^{5}$ The earliest attestation of Pan's cult was in Arcadia where he was venerated in built edifices since the Archaic period and had a kourotrophic function. The goat-god was introduced to Attica after the Persian Wars and in Boeotia a little later, but, in contrast to Arcadian custom, in these regions he received cult jointly with the Nymphs in caves that were originally sacred only to the latter. ${ }^{6}$ In the course of the $5^{\text {th }} \mathrm{c} . \mathrm{BC}$, Pan, master of all fears and lord of panic landscapes, gains popularity as a deity that is sympathetic to humans and supportive to them in critical situations.

Pan's presence in Boeotia is a rather unexplored topic and is briefly sketched below on the basis of the abundant but partially published coroplastic material from the Leibethrian cave as well as of the few terracottas and vases from the Kabirion and elsewhere. Although usually seen as a pastoral deity best fitted for this agricultural region, Pan's interstitial and "wild" nature makes him also an apt overseer of transient situations and states of being, such as ephebic maturation rites. Pan's presence in the art of Boeotia is rather limited, but the concentration of figurines and vases depicting him in specific cult-places deserves comment and a new interpretive approach.

\section{The Archaeology of Pan's Cult in Boeotia: Figurines and Reliefs, Sanctuaries and Graves}

4 Following the Attic patterns of his cult in the wake of the Persian Wars, Pan was installed in grottoes sacred to the Nymphs also in Boeotia. ${ }^{7}$ Best known is the cave of the Leibethrian Nymphs, which is located in the northern outcrops of mount Helicon, at the vicinity of Lebadea. The cult of the Leibethrian Nymphs is attested epigraphically from the Archaic period onwards, while Pan's veneration is documented only by his terracotta effigies, a rich series dating from the Classical to the Hellenistic period. ${ }^{8}$ The excavators of the cave report 300 figurines classified under at least 20 different types. ${ }^{9}$ In the 5th c. BC the coroplasts fashion the caprine god in a mixed humanoid and animal form, i.e. with caprine facial features such as horns, snub nose and thick-lipped mouth as well as male torso and goat legs (Figs. 1-2). 
Figs. 1-2. Figurines of Pan from the Heliconian cave of the Leibethrian Nymphs, Boeotia

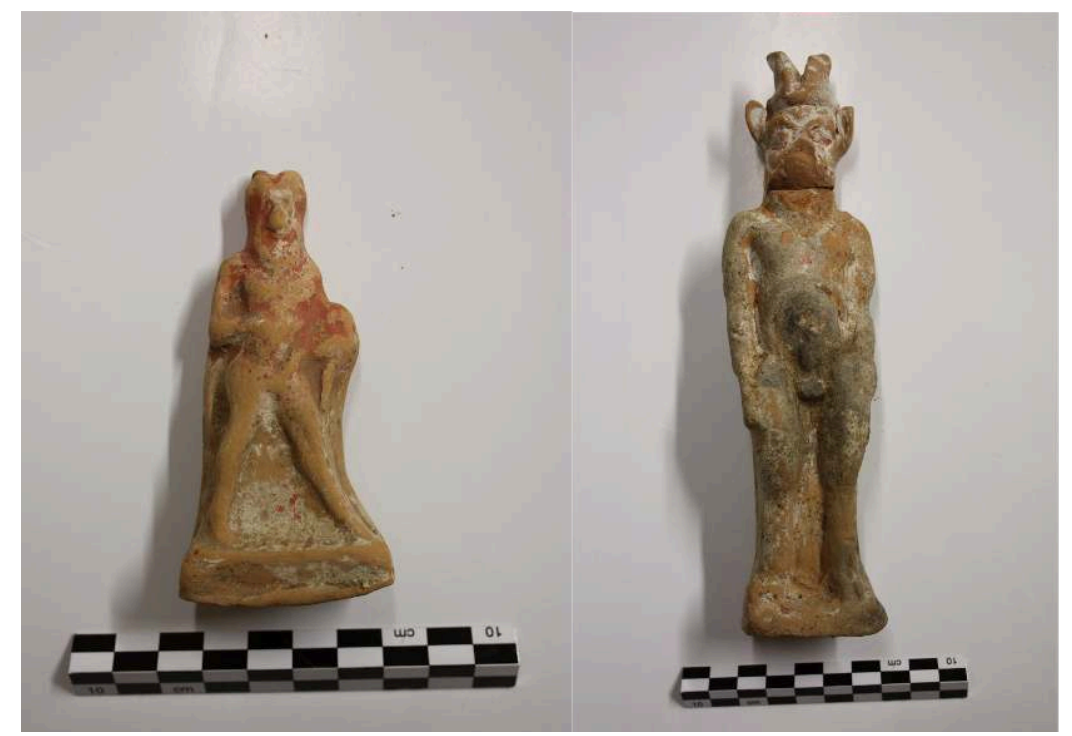

Courtesy of the Ephorate of Palaeoanthropology and Speleology and V. Vassilopoulou

5 He usually holds a horn and his favorite musical instrument, the syrinx, while in the latter part of the $5^{\text {th }} \mathrm{c}$. BC he may be featured with a lagobolon, a stick for striking hares. The goat-god's occasional ithyphallism stresses his animalistic sexuality and likens him to the figure of the satyr, with whom he is often affiliated in the art of the Classical period. ${ }^{10}$ Landscape is rarely depicted as background of these figurines, except for rare examples that show him among stones and in the company of a dog. ${ }^{11}$ From the $4^{\text {th }} \mathrm{c} . \mathrm{BC}$ onwards and in keeping with a tendency towards anthropomorphism, Pan may appear with human legs and occasionally youthful facial features.

6 A group of terracotta figurines depicting Pan were also unearthed in the Sanctuary of the Kabiroi, where the goat-god's cult is otherwise unattested..$^{12}$ This long-lived cultplace housed a mystery cult that was characterized by Dionysiac underpinnings and a custom-made ceramic vessel bearing unique comic imagery, i.e. the Kabiric skyphos. Maturation rituals for the Theban boys have been surmised on the basis of the material and the imagery circulating in the sanctuary. ${ }^{13}$ The coroplastic repertoire is mainly comprised of little boys, youths holding animals associated with adolescence such as cocks, and symposiasts, thus males presented in types that are characteristic of their age-class and its respective ritual and social roles. ${ }^{14}$ The figurines of Pan from the Kabirion may be best understood as offerings of males on the occasion of their maturation, ${ }^{15}$ which must be valid also for the Heliconeian cave. ${ }^{16} \mathrm{~A}$ deity that is halfbeast, half-man is appropriate to accompany individuals in transition and we should be precluded from treating Pan narrowly as a pastoral god. It should be further noted that a simile likening adolescent males and goats existed in ancient imagination, which in Boeotia found artistic but also cultic expression. ${ }^{17}$ Pan's figurines from the Kabirion are in the usual types of the $5^{\text {th }}$ and $4^{\text {th }} \mathrm{c}$. BC as known from the grotto, but it is of interest that he appears also in other media and art forms. A $4^{\text {th }} \mathrm{c}$. BC terracotta relief depicts him with his palm shading his eyes in order to see better (aposkopeuon), a ritual gesture performed by satyrs searching the horizon in anticipation of Dionysos' epiphany. ${ }^{18}$ Further, and in contrast to votive practice in the Heliconeian cave where Pan is absent from the repertoire of the figured ceramics, in the Kabirion he is repeatedly shown also 
on vases. The issue is of importance for understanding the nature of the cult at the Kabirion and the identity of the worshippers frequenting it, as we shall see further below.

7 Pan's presence in Boeotia was more widespread than currently attested in the material evidence from its excavated sanctuaries. Several terracottas depicting him in various types were also found in the region's necropoleis. ${ }^{19}$ Further, the testimonia mention Pindar's erection of a shrine close to his home in Thebes, where joint cult was offered to Pan and the Mother of the Gods in acknowledgment of the former's singing the poet's paeans. A little before $474 \mathrm{BC}$ this cult comprised all night celebrations (pannychides) and a maiden chorus, ${ }^{20}$ and apparently attests to the integration of a divinity of the wild eschatiai in urban space ${ }^{21}$ as well as to Pan's ties with individual worshippers.

8 Sculptures from Thespiai provide evidence about the god's worship also in that area. A now lost fragmentary relief dated by Chrestos Karouzos to the beginning of the $4^{\text {th }} \mathrm{c}$. BC on the basis of its votive inscription is important for its depiction of landscape (Fig.3).

Fig. 3. Relief depicting Pan above his cave, lost

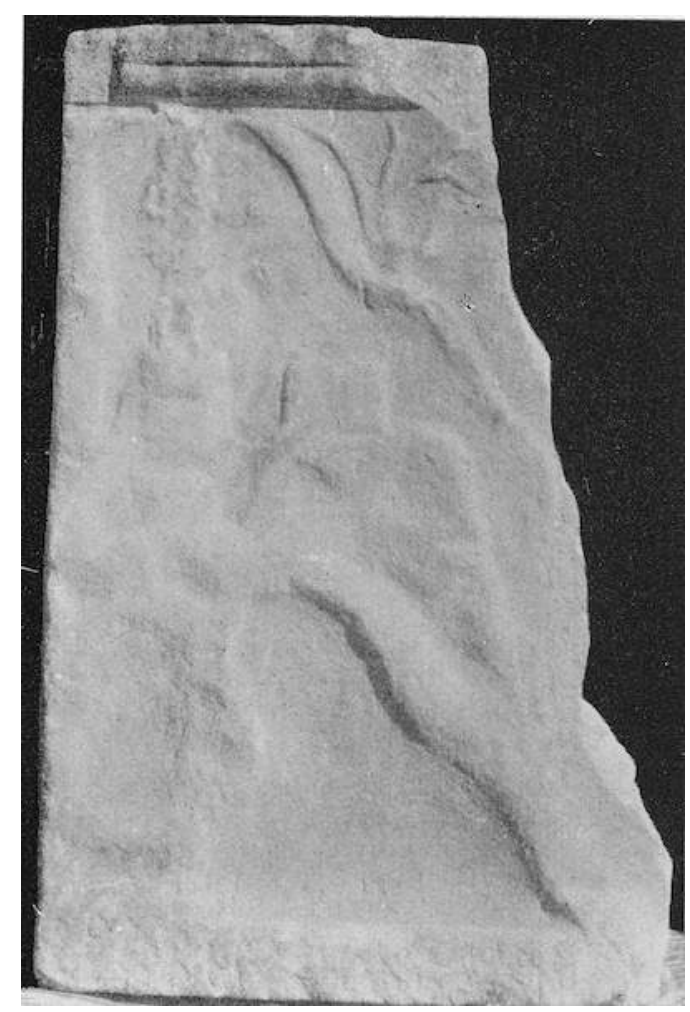

From kAROUZOS 1934, fig. 32

9 The wide opening of a cave occupies the lower part of the scene, while at its upper part Pan in small scale stands on a base-like rocky escarpment facing an altar, and behind the contour-line of the mountainside is a tree. Landscape elements denoting rustic wilderness, such as an abundance of rocky formations, predominate in this remarkable scene and they would have once been part of a broader, multi-figured composition. ${ }^{22}$ On another, mid $4^{\text {th }} \mathrm{c}$. BC relief in Berlin, a youthful Pan plays with his dog next to Dionysos in a cavernous landscape. ${ }^{23}$ The goat-man's relationship with the god of wine 
is not fortuitous, as the latter's associations with concepts of wildness and transformation are well-known and attested also in vase-imagery, as is also seen below.

\section{Pan in Boeotian Vase-painting: The Early Examples}

10 Before looking at Pan on Boeotian vases, we shall sketch an outline of his depiction in Attic painting of the $5^{\text {th }}$ and $4^{\text {th }} \mathrm{c}$. BC. The remodeling of the goat-god's cult which resulted to his affiliation with the cave-inhabiting Nymphs found little reflection in Attic vase-iconography, where caverns are rarely depicted and are usually associated with monstrous creatures. ${ }^{24}$ Instead, the earliest Attic iconographic examples feature Pan in sympotic and Dionysiac contexts, ${ }^{25}$ while from the second quarter of the 5th c. $\mathrm{BC}$ onwards there exist images that link Pan with the sphere of Eros, Aphrodite and the mortal bride. ${ }^{26}$ The frightful god appears rather benign to maidens in innovative imagery of the Classical period, as on an Attic chous which depicts him at the mouth of his cave addressing a nubile girl who has trespassed his realm unawares on her way to a spring. ${ }^{27}$ In the $4^{\text {th }} \mathrm{c}$. BC the Dionysiac and the Aphrodisian sphere merge in the popular image of the sacred wedding, where Pan plays the role of an attendant. ${ }^{28}$ Caves continue to be infrequently depicted at this time, except for the so-called anodos scenes where a model bridal female emerges from the earth in a grotto while Pan and other interstitial deities, such as Hermes, look on. Scholarly opinion has pointed to the initiatory meaning of this type of imagery, whereby Pan mediates the maiden's passage to the upper world as an observer, ${ }^{29}$ while the cavernous setting accentuates the liminality of the situation. ${ }^{30}$

11 This brief outline of Pan's appearance in Attic vase-painting may serve as background to the Boeotian one, which is influenced by it but does not imitate it slavishly. It can be generally said that Pan is represented infrequently in Boeotian vase-painting. His most repeated appearance is on Kabiric skyphoi, while rocky landscape is rarely featured. He is further shown as part of the Dionysiac thiasos on $4^{\text {th }} \mathrm{c}$. BC Attic imports and locally produced Atticizing vases. The main difference between Boeotian and Attic vase-images of Pan is that some of the former belong to a comic visual genre and functioned in the particular epichoric cultic context of the Kabirion sanctuary.

12 As to the earliest depictions of Pan on Boeotian vases, these are far from certain. A. D. Ure proposed to see Pan in a male figure with goat-like legs riding a lion on an Archaic Boeotian lekane by the Triton Painter, a view that is based on the testimonium mentioning Pindar's joint cult of Pan and the Great Mother, whose sacred animal was the lion (Fig.4). ${ }^{31}$ 
Fig. 4. Boeotian black-figure lekane

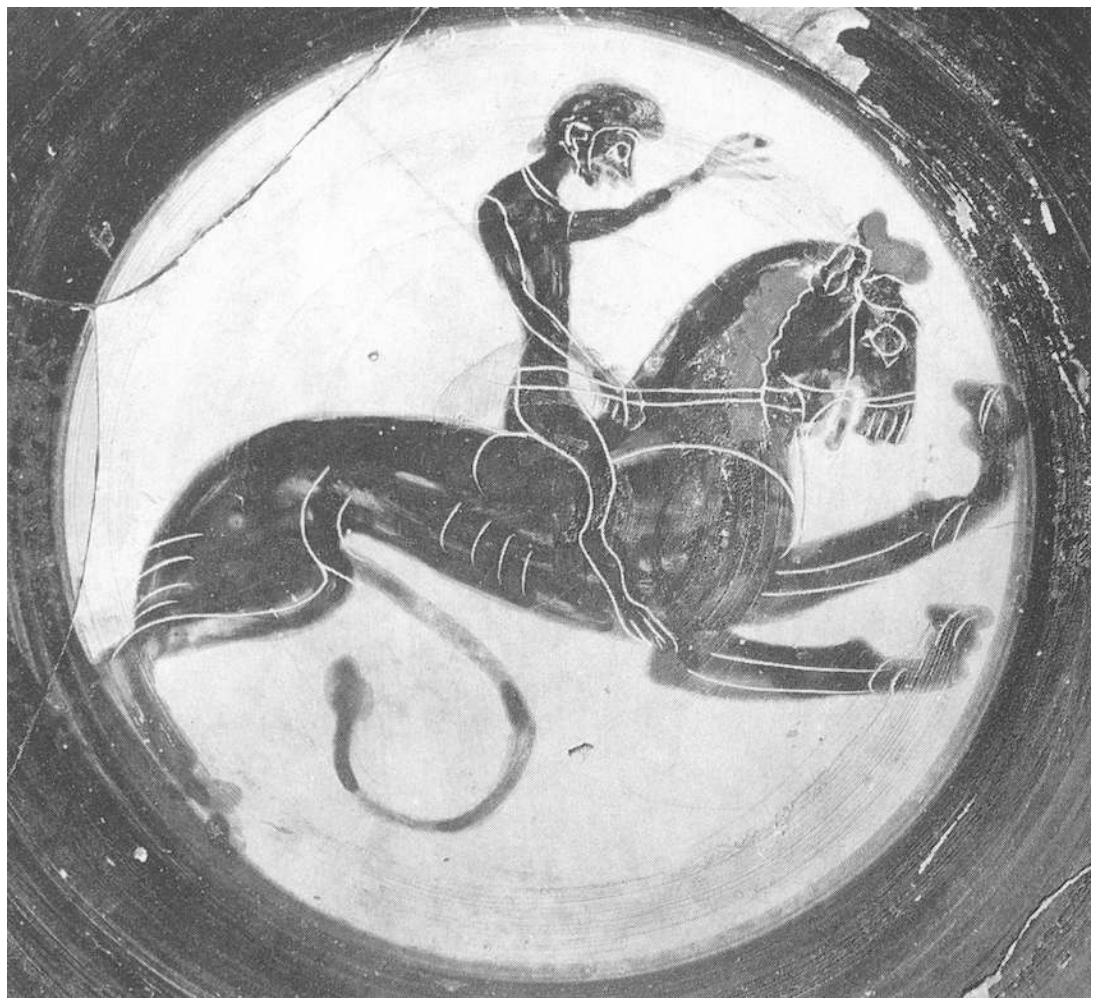

From KILINSKI 1990, pl. 27, 3

13 The lack of horns makes the identification uncertain ${ }^{32}$ and one wonders whether the form of the legs is just an awkward attempt to render the thigh in profile and the shank in frontal view, or whether the figure in his tight outfit is a komast with deformed legs in an imaginary ride. Leaving this dubious early example aside, the next attestation of Pan in local black-figure painting is on a Haimoneian cup in Würzburg that was originally thought Attic by A. D. Ure and provincial Attic-Boeotian by E. Simon, but which is currently rightly regarded as Atticizing Boeotian (Fig. 5). ${ }^{33}$

Fig. 5. Boeotian black-figure cup
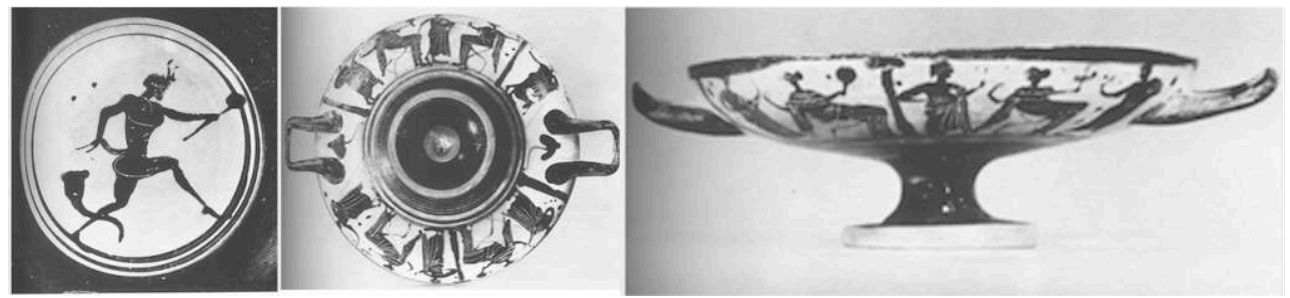

From simon 1972, pl. 4: 1, 3, 5

The cup dates in the second quarter of the $5^{\text {th }} \mathrm{c} . \mathrm{BC}$, probably towards its middle, and its style of drawing is indebted to products of the Haimon Painter's workshop. ${ }^{34}$ On the intaglio Pan is depicted horned, but with human legs, running with an object that may be a lagobolon in his hand, ${ }^{35}$ while at the background a drinking horn is featured. On the cup's exterior a multi-figured scene with male and female figures in a domestic space is repeated on both sides. Although interpreted as hetairai, the mirrors and exaleiptra, containers of aromatics, held by the well-dressed and stately seated women suggest 
interaction of the sexes in a domestic context with nuptial underpinnings. ${ }^{36}$ Such scenes occur in Attic red-figure of the second quarter of the $5^{\text {th }} \mathrm{c}$. BC and should be seen as codified images referring visually to prospective grooms encountering bridal females in the space of the oikos. More than one couple is depicted here, while the extra male may be a relative. The iconographic association of Pan with nubile women on the Atticizing Würzburg cup suggests that the links of Pan with the Aphrodisian realm were widely known and informed even the mass-produced vase-art of the Haimoneian workshop, products of which were imported and copied in Boeotia even after the onset of Attic red-figure. ${ }^{37}$ Such sloppy scenes are not devoid of content but rather stereotyped images of well-known themes, the meaning of which would have been familiar to everybody.

\section{Pan in Boeotian Red-figure and Kabiric Ware: Male Identity Seen Humorously}

15 Pan is attested in canonical form in Boeotian vase-iconography of the latter part of the $5^{\text {th }} \mathrm{C}$. BC, namely on a red-figure skyphos and various Kabiric ones, ${ }^{38}$ where he is predominantly associated with the music of wind and percussion instruments. The difference between the red-figure skyphos and the Kabiric ones is that the former highlights the bodily transformations brought about when coming of age, while the latter prioritize boisterous dance in a mocking spirit and in a context of initiatory celebration.

16 The small red-figure skyphos by the Painter of the Dancing Pan in Kassel (ca. 420 BC) juxtaposes a beardless and a bearded Pan on either side (Fig. 6a-b). ${ }^{39}$

Fig. 6a-b. Boeotian red-figure skyphos Kassel, inv. no. T 426

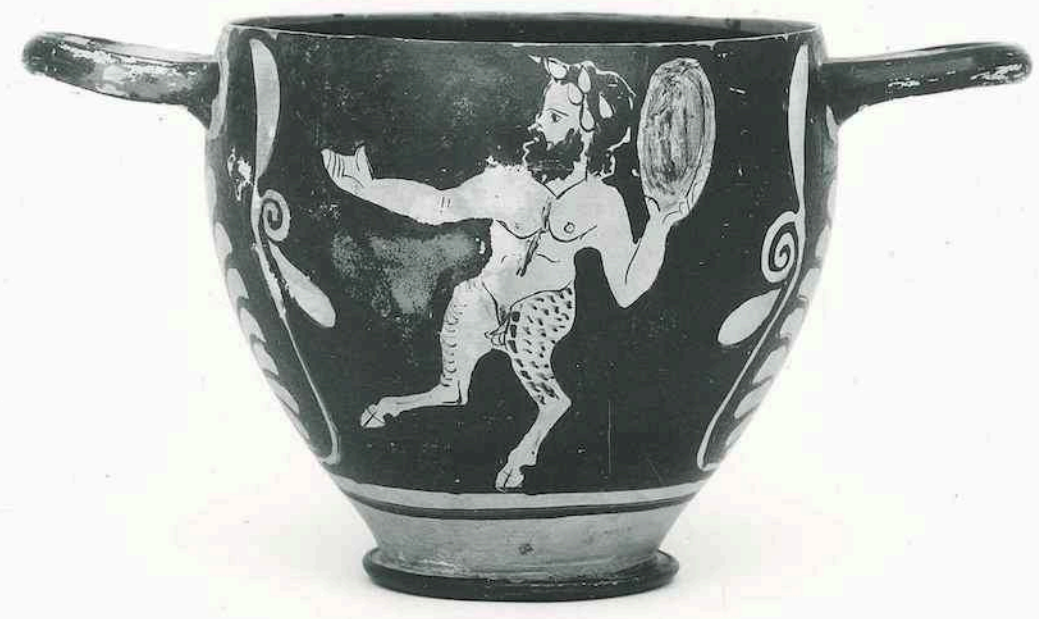




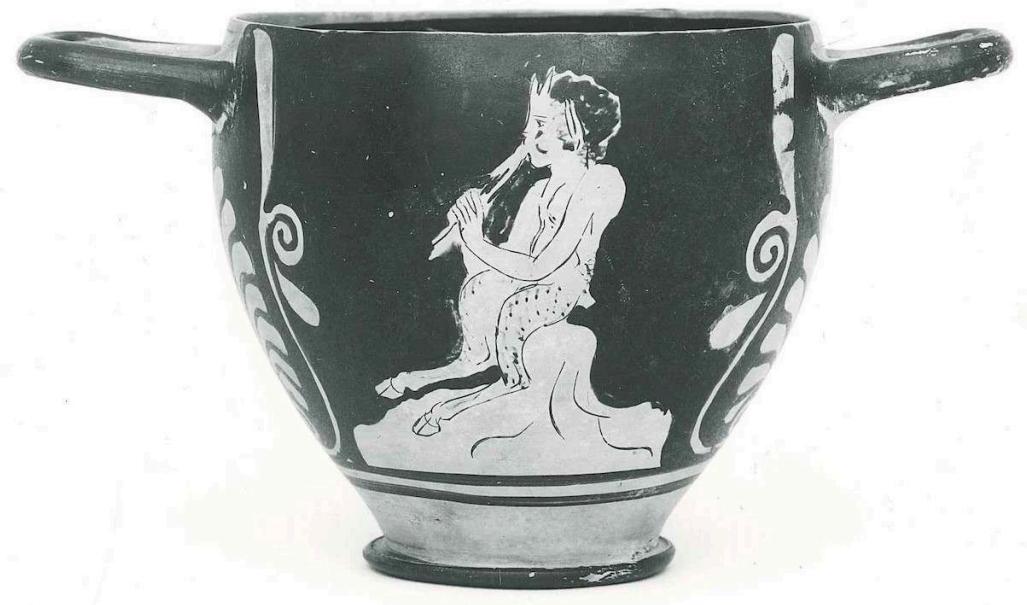

Courtesy of Museumslandschaft Hessen Kassel, Antikensammlung Schloss Wilhelmshöhe

17 The painter depicts him in two subsequent age-classes, as an ephebe and as a mature adult, and therefore casts him not as an ageless divinity, but as the mythological equivalent of the mortal male with a biography. The distinct differences between adolescence and manhood are pictured as transformations of the goat-god's body. Pan, the ephebe, has small horns, animal ears, beardless face with ephebic sideburns (iouloi), and soft fur on his goat-legs. His torso is that of a child and his genitals remain concealed as he is seated on a rock piping. Pan, the mature male, has a thick beard, a hairy head and wears a myrtle wreath, the leaves of which cover his animal ears and horns. His body is robust and he is depicted in a posture that allows his genitals to be displayed, while thick strokes denote the rich fur covering his legs. No rock appears with Pan senior and he is not seated but dances with a drum in his hand. Note that the boulder depicted as the young Pan's seat has multiple functions: as landscape element it recalls the goat-god's rocky abodes and as iconographic sign it refers to his hybrid nature and his marginal status as adolescent on the brink to manhood. ${ }^{40} \mathrm{Pan}$ in the guise of the mature goat-man is no longer in the sphere of undomesticated wilderness: his wreath and tambourine cast him as participant in festive celebrations or processions such as those performed by citizens. It would be pedantic to ask whether one and the same or two Panes in subsequent ages were meant here ${ }^{41}$ for the important thing is to highlight the different identities that individuals assume in various life-phases; to be noted, the whole process is conceived of and pictured as a bodily experience. This is not the first time that a Boeotian artist purposefully contrasts young and mature individuals on the two sides of the same artefact in order to stress the importance of the successful passage and the social integration of

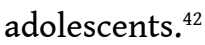

18 A last point about Pan's double appearance on the Kassel skyphos concerns the mode in which its imagery is tuned: is it formal or rather mildly humorous? Can a figure of the wilds ever become "civilized" when leaving the wildness of adolescence behind? Or was the imagery of Pan in two age-classes meant to provoke a smile, as it happens with satyrs assuming the roles of humans? ${ }^{43} \mathrm{~A}$ subtle humor may be discerned in the skyphos' imagery that accords well with the playful spirit attested also in other 
Boeotian red-figure scenes including those by the Painter of the Dancing Pan. The use of hybrid animal-human figures and the complementarity of subject-matter on the same vessel as means in the creation of visual humor in this class of artefacts is notable and often related to coming of age. ${ }^{44}$ The Boeotian interest in maturation themes can be explained by the function of (Attic and Boeotian) red-figure wares as gifts to adolescents in life and death and presumably also as ephebic offerings to the sanctuaries. ${ }^{45}$ To be sure, the social uses of artefacts determine their iconography and the meanings that are vehiculated by them.

Pan's most frequent appearance in Boeotian painting is on a special group of vases, mostly skyphoi, that were locally produced for votive use at the Kabirion sanctuary from the last quarter of the $5^{\text {th }}$ to the $4^{\text {th }} \mathrm{c}$. BC. The Kabiric skyphoi are decorated with parodies of well-known myths, as well as with symposia and floral motifs, usually vines with grapes. They were produced in various sizes for votive function in a sanctuary that hosted a mystery cult with Dionysiac underpinnings and presumably also a celebration of maturation rituals, as previously noted. ${ }^{46}$ The goat-god's appearance in a variety of odd postures and contexts on Kabiric skyphoi is remarkable. He is featured mostly goat-legged, only occasionally with horns, ${ }^{47}$ and in a wide range of roles, from agitated dancer and musician to cultic acolyte. ${ }^{48}$ In most of the examples Pan is piping and frolicking in convoluted frontal postures of raucous dancing in the company of grotesque revelers, satyrs and masqueraded men who are featured in various areas of the vase. ${ }^{49}$ Humor is produced by the goat-god's postures as well as by his hanging genitals that echo those of his fellow revelers (Fig. 7).

FIG 7. Kabiric skyphos Athens, National Archaeological Museum inv. no. 545

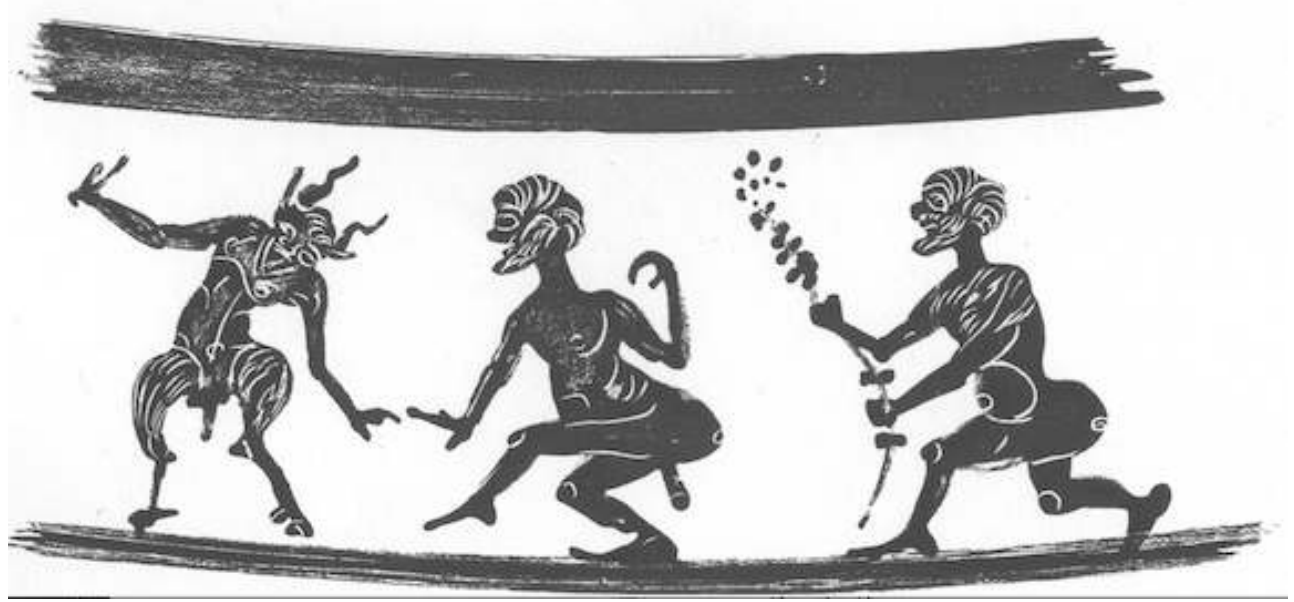




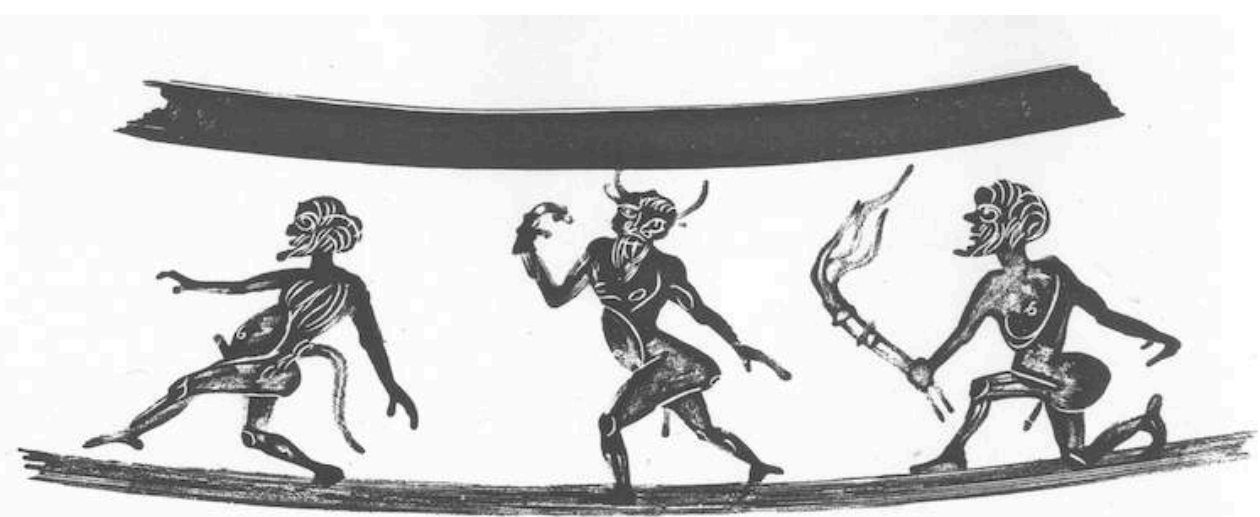

From WOLTERS-BRUNS 1940, pl. 32: 1-2 holding a tambourine in front of a seated female flute-player. His posture suggests either acrobatic dance or falling over with lust before the desirable woman, a comic scene (Fig. 8 a-b). ${ }^{50}$

Fig. 8. Kabiric skyphos Brussels A 2627

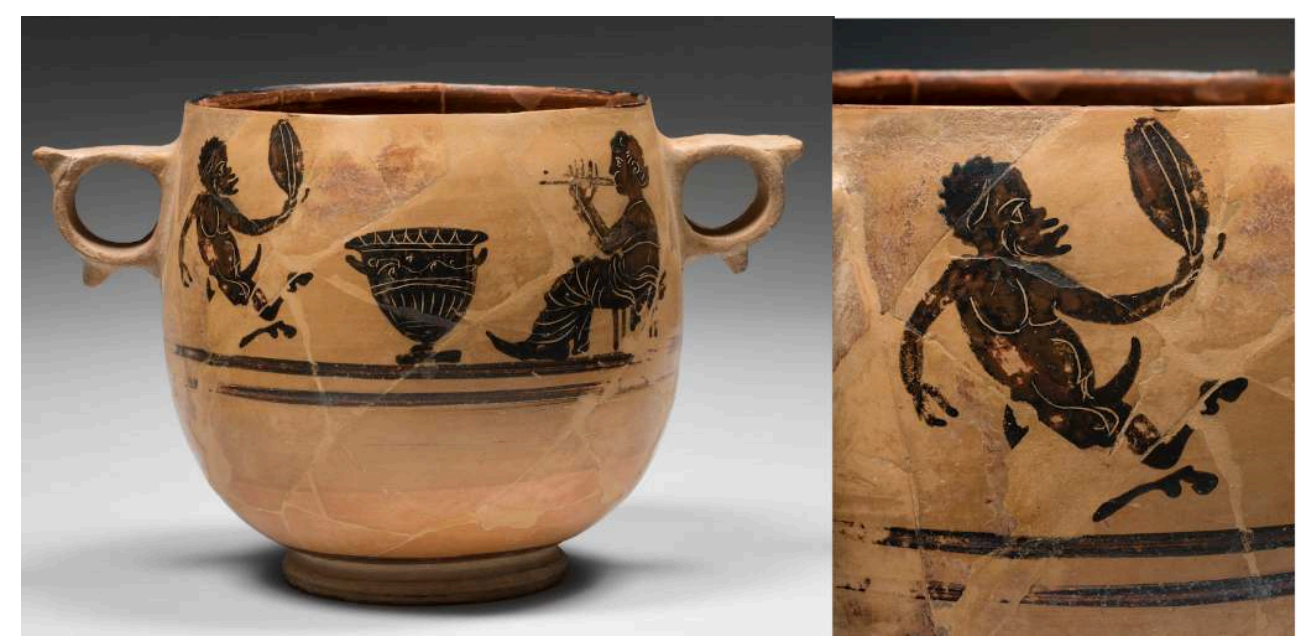

Courtesy Musées Royaux d'Art et d'Histoire, Brussels. Photo by R. Pessemier

The krater and the furniture in the scene associate Pan with the human realm and may suggest a wish to acculturate and incorporate him into the civilized urban space. In this conceptual frame Pan could be further pictured as partaker of sacrifices and processions that were patterned on the ritual activities of the citizens themselves, ${ }^{51}$ as on a single fragmentary Kabiric skyphoswhere he holds a tray of cakes and follows a thyrsos-bearing satyr in a context of ritual celebration..$^{52}$ The appearance of Pan with a satyr in a Kabiric scene offers one more indication of the Kabiric cult's Dionysiac underpinnings. ${ }^{53}$ On another remarkable Kabiric skyphos once in Berlin, Pan appears in a rocky landscape with his father Hermes who offers him festive bands and twigs. ${ }^{54}$ The emphasis on the father-son relationship in a scene where a parent introduces his son to the cult of the Kabiroi may reflect further the concern for the initiation of the young Boeotian males into the rank of mature citizens. ${ }^{55}$ 


\section{A Note on Pan in $4^{\text {th }}$ c. BC Atticizing Vase-painting}

We end this small survey of Pan's appearance in Boeotian figured vases with a look at the $4^{\text {th }}$ c. BC. As already noted, Attic vase-painting of this era often depicts Pan observing hierogamia scenes in the company of the thiasos who witnesses the Dionysiac couple's attainment of a happy state of being. This type of imagery visualizes the marital union as imbued with notions of bliss, while Pan's appearance recalls his mediating role and highlights the accomplished transition. Vases bearing hierogamia imagery may have been propitious wedding gifts that accompanied their owners to their grave at a later point in time. Thus, Dionysos' and Ariadne's blissful union observed by Pan is an image that could acquire a double meaning according to its use and viewing context in life or death: it could refer visually both to a model divine marriage and, secondarily, to the afterlife bliss that was visualized as the Dionysiac wedding. Imagery of this type was known to Boeotians via Attic imports, such as the hydria by the Hesperides Painter which depicts the sacred union of Dionysos and Ariadne, with Pan featured in a humanized form. ${ }^{56}$ Worthy of a more extensive study than possible here is the case of the Atticizing L.C. Group where Pan occurs in complex scenes comprising Dionysos and Ariadne, as well as Heracles in the Garden of the Hesperides. ${ }^{57}$ Although widely seen as funerary and associated with the afterlife, monumental vases by the L.C. Group were actually also dedicated to sanctuaries, thus they had an important role to play also in life's milestones. ${ }^{58}$

\section{Concluding Note}

Pan as an interstitial deity of the wilds, and for this reason an appropriate overseer of the transitional phases of human life, is as popular in Boeotia as he is in Attica. In the $5^{\text {th }}$ and $4^{\text {th }} \mathrm{c}$. BC he appears mostly in terracotta effigies from Boeotian graves and sanctuaries, such as the Kabirion and the grotto of the Leibethrian Nymphs. Of these, the former is an important extra-urban cult place with built edifices which was controlled by the city of Thebes, while the latter a natural cave in the wilderness of the Heliconeian mountain. Pan's figurines should be associated primarily with the status of the worshippers who dedicated his images in anticipation of a safe transition to adulthood, or in thanks for its achievement.

The issue of transformation brought about by age, of interest to Boeotian vase-painters, is exemplified also via the figure of the goat-god and his interstitial realm. The Painter of the Dancing Pan juxtaposes a young and a mature Pan on the same vase in order to picture the transformation of the male body when coming of age. The goat-god appears prominently on Kabiric ware. The now lost example where Pan is depicted in a fatherson relationship in a context of initiation highlights his associations with maturation. In most of the Kabiric examples Pan assumes comic postures as well as cultic roles in scenes of revelry and Dionysiac activity. This iconography should be analyzed within the context of the derisory humor that characterizes Kabiric imagery, which often uses figures of fear for comic purposes. Pan's hybrid nature and bodily appearance were instrumental in the creation of visual humor via odd postures and antics recalling unrestrained and lascivious goats. Such images accorded well with the ritual laughter ${ }^{59}$ that must have formed part of the Kabiric religious experience and cult. 


\section{BIBLIOGRAPHY}

ASTON 2011 : E. M. M. Aston, Mixanthrôpoi: Animal-human Hybrid Deities in Greek Religion, Liège 2011 (Kernos, suppl. 25).

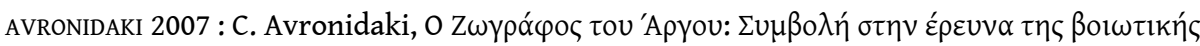

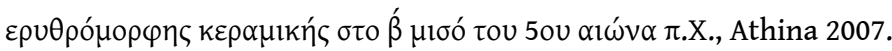

AVRONIDAKI 2008 : C. Avronidaki, « Boeotian Red-figure Imagery on Two New Vases by the Painter of the Dancing Pan», Antike Kunst 51 (2008), 8-22.

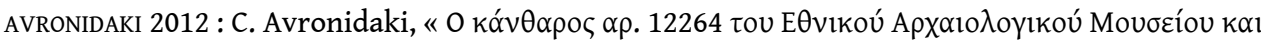

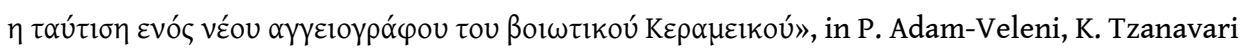

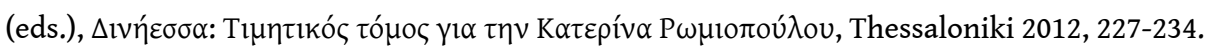

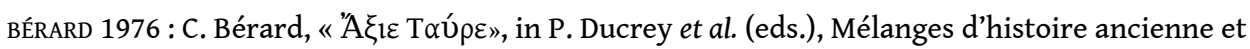
d'archéologie offerts à Paul Collart, Lausanne 1976, 61-73.

BOARDMAN 1997 : J. Boardman, s.v. Pan, LIMC VIII, 1997, 923-941.

BONACASA 1958 : N. Bonacasa, « Askos Locrese nello stile del Kabirion», Archeologia Classica 10 (1958), 50-54.

BORGEAUD 1988 : Ph. Borgeaud, The Cult of Pan in Ancient Greece (translated by K. Atlass, J. Redfield), Chicago 1988 [French original: Recherches sur le dieu Pan, Genève 1979].

BRAUN, HAEVERNICK 1981 : K. Braun, T. E. Haevernick, Bemalte Keramik und Glas aus dem Kabirenheiligtum bei Theben, IV, Berlin 1981.

BROMMER 1956 : F. Brommer, s.v. Pan, RE, Suppl. VIII, 1956, 949-1008.

BUXTON 1992 : R. Buxton, « Imaginary Greek Mountains», Journal of Hellenic Studies 112 (1992), 1-15.

CSAPO 2003 : E. Csapo, « Dolphins of Dionysus», in E. Csapo, M. C. Miller (eds.), Poetry, theory, praxis : the social life of myth, word and image in ancient Greece : essays in honour of William J. Slater, Oxford 2003, 69-98.

CUCUZZA 2009 : N. Cucuzza, « Una rappresentazione arcaica di Pan a Creta? Note su una placchetta litica da Festòs », Creta Antica 10/I (2009), 301-319.

DELIVORRIAS, BERGER-DOER, KOSSATZ-DEISSMANN 1984 : A. Delivorrias, G. Berger-Doer, A. KossatzDeissmann, s.v. Aphrodite, LIMC II, 1984, 2-151.

DIETRICH 2010 : N. Dietrich, Figur ohne Raum? Bäume und Felsen in der attischen Vasenmalerei des 6. und 5. Jahrhunderts v. Chr. (Image and Context, 7), Berlin 2010.

EDWARDS 1985 : Ch.M. Edwards, Greek Votive Reliefs to Pan and the Nymphs, Diss. New York University, 1985.

ELLINGER 2002 : P. Ellinger, « Artémis, Pan et Marathon: mythe, polythéisme et événement historique», in S. des Bouvrie (ed.), Myth and Symbol I: Symbolic Phenomena in Ancient Greek Culture (Papers from the First International Symposium on Symbolism at the University of Tromsø, June 4-7, 1998), Bergen 2002 (Papers from the Norwegian Institute at Athens, 5), 313-332.

FERRARI 2004 : G. Ferrari, « The ‘Anodos' of the Bride», in D. Yatromanolakis, P. Roilos (eds.), Greek Ritual Poetics, Washington, D.C., 2004, 245-260. 
GAIFMAN 2008 : M. Gaifman, «Visualized Rituals and Dedicatory Inscriptions on Votive Offerings to the Nymphs», Opuscula 1 (2008), 90-103.

GARLAND 1992: R. Garland, Introducing New Gods. The Politics of Athenian Religion, London 1992.

GOLDMAN-JONES 1942 : H. Goldman, F. Jones, « Terracottas from the Necropolis of Halae», Hesperia 11 (1942), 365-421.

HALDANE 1968: J.A. Haldane, « Pindar and Pan: frs. 95-100 Snell», Phoenix 22 (1968), 18-31.

HALLIWELL 2008 : St. Halliwell, Greek Laughter: A Study of Cultural Psychology from Homer to Early Christianity, Cambridge/New York 2008.

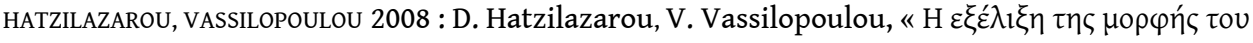

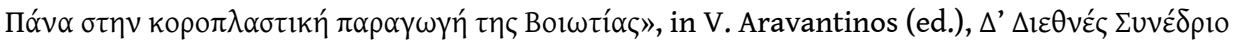

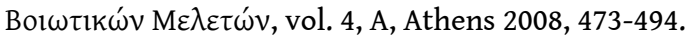

HEINEMANN 2016 : A. Heinemann, Der Gott des Gelages: Dionysos, Satyrn, und Mänaden auf attischem Trinkgeschirr des 5. Jahrhunderts v. Chr. (Image and Context 15), Berlin 2016.

HEINEMANN 2019 : A. Heinemann, « The Cave, the Gaze, the Bride, and her Lover. The Constraints of Narrating Desire on a Hellenistic Mirror», in E. Wagner-Durand, B. Fath, A. Heinemann (eds.), Image - Narration - Context, Heidelberg 2019, 335-369.

HÜBINGER 1992 : U. Hübinger, « On Pan's Iconography and the Cult in the Sanctuary of Pan on the Slopes of Mount Lykaion", in R. HÄGG, (ed.), The Iconography of Greek Cult in the Archaic and Classical Periods. Proceedings of the First International Seminar on Ancient Greek Cult, organised by the Swedish Institute at Athens and the European Cultural Centre of Delphi, 16-18.11.1990, Liège 1992 (Kernos Suppl. 1), 189-207.

HUYSECOM-HAXHI 2015 : S. Huysecom-Haxhi, « Du coq au canthare. Images de l'initiation masculine dans la coroplathie béotienne à l'époque classique», in S. Huysecom-Haxhi, A. Muller, (éds.), Figurines grecques en contexte. Présence muette dans le sanctuaire, la tombe et la maison, Villeneuve d'Ascq 2015, 71-89.

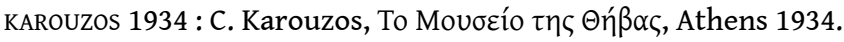

KATHARIOU 2009 : K. Kathariou, CVA Athens, Cycladic Museum 1, Athens 2009.

KILINSKI 1990 : K. Kilinski, Boeotian Black Figure Vase Painting of the Archaic Period, Mainz am Rhein 1990.

KRASILNIKOFF 2008: J. A. Krasilnikoff, « Pan, Attica and Religious Innovation from the Persian Wars to the End of the Fourth Century BC», in A. Holm Rasmussen, S. William Rasmussen, I. Gradel, J.A. Krasilnikoff, K. Rørby Kristensen (eds), Religion and Society. Rituals, Resources and Identity in the Ancient Graeco-Roman World: Analecta Romana Instituti Danici Supplementum XL, Rome 2008, 189-200.

LARSON 2010 : J. Larson, « A Land Full of Gods: Nature Deities in Greek Religion», in D. Ogden, (ed.), A Companion to Greek Religion, Oxford 2010, 56-70.

LEBESSI 1991 : A. Lebessi, « Flagellation ou autoflagellation: données iconographiques pour une tentative d'interprétation», Bulletin de Correspondance Hellénique 115, (1991), 99-123.

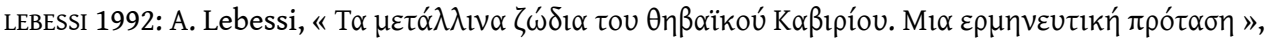
Archaiologike Ephemeris 1992, 1-19.

LISSARRAGUE 2013 : F. Lissarrague, La cité des satyres: une anthropologie ludique (Athènes, VIe-Ve siècle avant J.-C.), Paris 2013. 
LONSDALE 1993 : L.H. Lonsdale, Dance and Ritual Play in Greek Religion, Baltimore 1993.

METZGER 1951 : H. Metzger, Les représentations dans la céramique attique du IVe siècle, Paris 1951.

MITCHELL 2009 : A. G. Mitchell, Greek Vase-Painting and the Origins of Visual Humour, Cambridge 2009.

PAOLETTI 1998 : O. Paoletti, « Frammenti di uno skyphos cabirico», in G. Capecchi, S. Bruni (eds.), Memoria di Enrico Paribeni, Roma 1998, 319-324.

PARKER 1996 : R. Parker, Athenian Religion. A History, Oxford 1996.

PETRIDOU 2015 : G. Petridou, Divine Epiphany in Greek Literature and Culture, Oxford 2015.

RITTER 2002 : St. Ritter, Bildkontakte. Götter und Heroen in der Bildsprache griechischer Münzen des 4.

Jahhunderts v.Chr., Berlin 2002.

SABETAI 2012 : V. Sabetai, « Looking at Athenian Vases through the Eyes of the Boeotians: Copies, Adaptations, and Local Creations in the Social and Aesthetic Culture of an Attic Neighbour ", in S. Schmidt, A. Stähli (eds.), Vasenbilder im Kulturtransfer: Zirkulation und Rezeption griechischer Keramik im Mittelmeerraum (CVA Deutschland Suppl. 5), Munich 2012, 121-137.

SABETAI 2014 : V. Sabetai, « The Wedding Vases of the Athenians: A View from Sanctuaries and Houses», Mètis n.s. 12 (2014), 51-79.

SABETAI 2018 : V. Sabetai, « Encountering Pan in the Wilderness: a Small chous in the Benaki Museum», Kernos 31 (2018) 141-166.

SABETAI, AVRONIDAKI 2018: V. Sabetai, C. Avronidaki, « The Six's Technique in Boiotia : Regional Experiments in Technique and Iconography», Hesperia 87 (2018), 311-385.

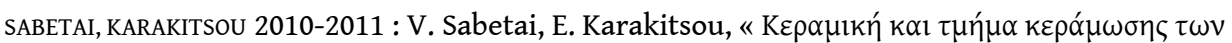

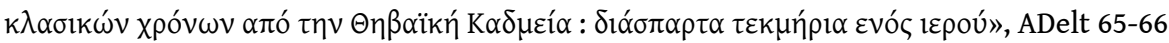
(2010-2011) [2016], 263-280.

SCHACHTER 1986 : A. Schachter, Cults of Boiotia, vol. 2 (BICS Suppl. 38.2), London 1986.

SCHACHTER 2003 : A. Schachter, « Evolutions of a Mystery Cult: The Theban Kabiroi», in M. Cosmopoulos (ed.), Greek Mysteries: The Archaeology and Ritual of Ancient Greek Secret Cults, London $2003,112-142$

SCHILD-XENIDOU 2008 : V. Schild-Xenidou, Corpus der boiotischen Grab- und Weihreliefs des 6. bis 4. Jahrhunderts v. Chr. (AthMitt Beih. 20), Mainz 2008.

SCHIRRIPA 2016 : P. Schirripa, « Il paesaggio sonoro di Pan», in G. Sena Chiesa - F. Giacobello (eds.), Gli dei in giardino: due convegni su mito, natura e paesaggio nel mondo antico, Sesto Fiorentino 2016, 113-118.

SCHMALTZ 1974 : B. Schmaltz, Terrakotten aus dem Kabirenheiligtum bei Theben: menschenähnliche Figuren, menschliche Figuren und Gerät, v. 5, Berlin 1974.

SCHÖNE-DENKINGER 2012 : A. Schöne-Denkinger, «Import und Imitation attischer Bilder in Böotien», in S. Schmidt, A. Stähli (eds.), Vasenbilder im Kulturtransfer: Zirkulation und Rezeption griechischer Keramik im Mittelmeerraum (CVA Deutschland 5), Munich 2012, 139-149.

SIEBERT 1990a : G. Siebert, s.v. Hermes, LIMC V, 1990, 285-387.

SIEBERT 1990b : G. Siebert, « Imaginaire et images de la grotte dans la Grèce archaïque et classique» , Ktèma 15 (1990), 151-161.

SIMON 1976 : E. Simon, « Ein Nordattischer Pan», Antike Kunst 19 (1976), 19-23. 
SLATER 1976 : W. J. SLATER, « Symposium at Sea», Harvard Studies in Classical Philology 80 (1976), 161-170.

SPORN 2013 : K. Sporn, « Mapping Greek Sacred Caves : Sources, Features, Cults», in F. Mavridis, J. Tae Jensen (eds.), Stable Places and Changing Perceptions : Cave Archaeology in Greece, Oxford 2013, 202-216.

URE 1932 : A. D. Ure, « Boeotian Orientalizing Lekanai», Metropolitan Museum Studies 4 (1932), 18-38. VASSILOPOULOU 2013 : V. Vassilopoulou, «Prehistoric Use and Ancient Ritual Worship at the Cave of Hagia Triada on Helikon», in F. Mavridis, J. Tae Jensen (eds.), Stable Places and Changing Perceptions: Cave Archaeology in Greece, Oxford 2013, 319-328.

VASSILOPOULOU, SKOUMI, NASSIOTI 2015 : V. Vassilopoulou, N. Skoumi, E. Nassioti, « Aphrodite figurines from the sanctuary of "Nymph Koronia" at mount Helicon», in E. Lafli, A. Muller (eds.), Figurines de terre cuite en Méditerranée grecque et romaine. 2: Iconographie et contextes, Villeneuve d'Ascq 2015, 473-480.

VoutiRas 2018 : E. Voutiras, « Pan en Macédoine», in M. Kalaitzi, P. Paschidis, Cl. Antonetti, A.-M.

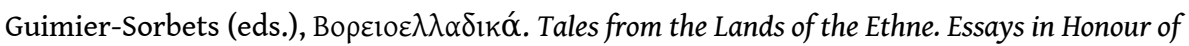
Miltiades B. Hatzopoulos, Athens 2018 (National Hellenic Research Foundation / Institute of Historical Research, Meletemata 78), 397-411.

WOLTERS, BRUNS 1940 : P. Wolters and G. Bruns 1940, Das Kabirenheiligtum bei Theben, I, Berlin 1940.

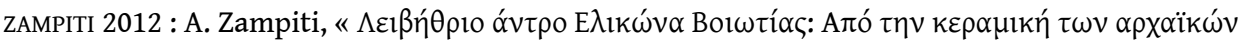

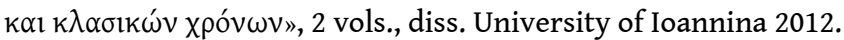

\section{NOTES}

1. Plutarch, Life of Numa 4.8, 62c $=\mathrm{T} 67$ Radt. "There is a legend, too, that Pan became enamored of Pindar and his verses. (transl. Loeb)".

2. On Pan see selectively BORGEAUD 1988; GARLAND 1992, 58-63; BOARDMAN 1997 (940: "Pan is the nearest the Greeks had to an all-animal deity"); ELLINGER 2002, esp. 327-330; PARKER 1996, 163-168; KRASILNIKOFF 2008; LARSON 2010, 63-64; ASTON 2011, 109-120; 272-277 and passim; PETRIDOU 2015, 201-205 ; VOUTIRAS 2018 ; SABETAI 2018.

3. For the space of the mountain and the sea in ancient imagination see BUXTON 1992 ; SLATER 1976; CSAPO 2003.

4. For land in remotis and the gods controlling it, see BORGEAUD 1988, 60 ; PETRIDOU 2015, 195-228.

5. For males transition was primarily associated with the symposion and war, while for females with marriage. Wedding vases retrieved from the Attic caves of Pan and the Nymphs attest to prenuptial visits and dedications which may be associated especially with female maturation, although future grooms may have also been involved : see SABETAI 2014, 68-69.

6. In general, cult activity in caves of central Greece including Boeotia starts earlier than in Attica : SPORN 2013, 205. Pan helped the Athenians control their fear and instilled panic in the Persian army at Marathon. The introduction of his cult in Attica may not simply express the polis' gratitude for his assistance but further suggests that the Athenians perceived of this battle also as a liminal situation. Its successful completion had a bearing on the "maturation" of a body of citizen-soldiers that glorified Athens in the following years.

7. For the various sources on Pan's cult in Boeotia see SCHACHTER 1986, 194-198. He is mentioned neither in Hesiod's nor in Homer's epics. 
8. For the cave-sanctuary of the Leibethrian Nymphs see ZAMPITI 2012, 23-30 and VASSILOPOULOU 2013 (general) ; HATZILAZAROU, VASSILOPOULOU 2008 (figurines of Pan) ; VASSILOPOULOU, SKOUMI, NASSIOTI 2015 (female figurines and varia). Cf. SCHACHTER 1986, 195 ( $2^{\text {nd }}$ c. BC rock-cut inscriptions mentioning Pan and Dionysos at a cave close to Lebadea).

9. VASSILOPOULOU 2013, 321 mentioning also fragments of a marble sculpture and a relief of Pan. The material depicting Pan is under publication and is only briefly known: see HATZILAZAROU, VASSILOPOULOU 2008, op. cit. n. 9, above.

10. LISSARRAGUE 2013, 114-117.

11. HATZILAZAROU, VASSILOPOULOU 2008, 493, fig. 15.

12. SCHMALTZ 1974, 9-17; 147-148, nos. 1-11, pl. 1 . The earliest examples date around the second quarter of the $5^{\text {th }} \mathrm{c} . \mathrm{BC}$.

13. LEBESSI 1992, esp. 5 ff. first pointed to issues related to maturation in conjunction with the mystery cult of the Kabiroi ; cf. also ThesCRA II.3.c. (2004) s.v. Initiation, 103 (W. Burkert) with earlier bibliography. Several toys unearthed in the site point further to the occasion of ephebic dedication. On the Kabirion in general see SCHACHTER 2003.

14. For discussion of these coroplastic types in the context of male maturation see HUYSECOMHAXHI 2015.

15. SCHMALTZ 1974, 9 ; 16-17 rightly rejects the earlier opinion that Pan figurines can be used as evidence for the cult of the goat-god in the Kabirion and points to a relationship with their dedicators, whom, however, he identifies with the peasants inhabiting the area around the sanctuary.

16. Most of the cave's terracottas and minor objects are females in bridal and matronal guise, clay pomegranates and apples, as well as knucklebones that may be associated with women's maturation and prospective female roles. The large number of Pan figurines may be interpreted as offerings by youths coming of age for whom the god was a kind of ritual alter ego. The cave's dim light and the sound of dripping water in an evocative and emotive landscape in the wilderness provide the perfect background for initiatory experiences of all kinds. For bibliography on the grotto see n. 9 , above.

17. SABETAI, AVRONIDAKI 2018, 361-362;367, no. B9.

18. SCHMALTZ 1974, 15-16; 138, no. 378, pl. 29 ; BOARDMAN 1997, 925, no. 27, pl. 614. In this example Pan is featured in human form and horns.

19. SCHACHTER 1986, 194-197. For an excavated example from Halai, where he is reclining as a banqueter see GOLDMAN-JONES 1942, 404, V.d.2, pl. XX (early $4^{\text {th }}$ c. BC). For this type cf. BOARDMAN 1997, 929, no. 124, pl. 622.

20. HALDANE 1968 ; SCHACHTER 1986, 197. For Pan in landscapes of sound cf. SCHIRRIPA 2016.

21. Similar practice is attested in Athens, where Pan's cult is housed in a cave at the north slope of the Acropolis, between the city and its temples.

22. KAROUZOS 1934, 37, no. 231 ; SCHILD-XENIDOU 2008, 212-213; 299-300, kat. 69, pl. 28. For an Attic relief of the late 5th c. BC depicting Pan in his cave see GAIFMAN 2008, 91-94.

23. SCHILD-XENIDOU 2008, 214 ; 325-326, Kat. 94, pl. 37.

24. For the iconography and iconology of caves and rocky landscapes in Attic art see BÉRARD 1976, 61-65 ; EDWARDS 1985, 59-63 ; SIEBERT 1990b ; DIETRICH 2010.

25. CVA Amsterdam, Allard Pierson Museum 5, pl. 268, 5 (BAPD 4916 ; ca. 490 BC) ; BOARDMAN 1997, 924, nos. 3 and 5, pl. 612.

26. For Pan and the Aphrodisian milieu see, BOARDMAN 1997, 933, nos. 191-196, pl. 626. DELIVORRIAS, BERGER-DOER, KOSSATZ-DEISSMANN 1984, 113, nos. 1158-1159, pl. $115 ; 113-114$, no. $1160 ; 128$, nos. 1343-1353, pls. 131-132; HEINEMANN 2019.

27. SABETAI 2018. 
28. For hierogamia scenes in the $4^{\text {th }}$ c. BC see METZGER 1951, 133-136.

29. BORGEAUD 1988, 145-146 ; LEBESSI 1991, 117-120 ; LONSDALE 1993, 265-266. FERRARI 2004.

30. For Pan as an observer in images of liminal character where the setting can be characterized as supernatural, a "panic landscape", see BORGEAUD 1988, 58-60.

31. URE 1932, 37 ; KILINSKI 1990, $46 ; 60$, pl. 27, 3.

32. The figures usually regarded as typological forerunners of Pan resemble goats rather than hornless, anthropomorphic figures : HÜBINGER 1992, 191, n. 3 ; CUCUZZA 2009.

33. simON 1976, 19ff., pl. 4 : 1, 3, 5 (ca. 475 BC) ; BOARDMAN 1997, 925, no. 21 (450 BC) BAPD 44630. For bibliography on these Atticizing Haimoneian cups see KATHARIOU 2009, text to pls. 44-49.

34. Boeotian copies of Attic Haimoneian vases are long-lived in Boeotia ; see below.

35. SIMON 1976, 20 opted for a torch ; doubted by BOARDMAN 1997, 925, no. 21. Cf. an Attic pelike in Compiègne where Pan holds a trumpet-like stick ending in a funnel : SIEBERT 1990a, pl. 215, no. 164 (460-450 BC ; BAPD 11136). Cf. further the club with rounded end in the hand of a hunting dwarf on a Lokrian askos : BONACASA 1958, pl. 15, 1.

36. The exaleiptra signify the seduction of aromatics and the mirrors female beauty, both conceptually related to nuptials. Boeotians picture their bridal females dressed also in later art.

37. Boeotian red-figure starts in the latter part of the $5^{\text {th }} \mathrm{c} . \mathrm{BC}$.

38. For Pan in Boeotian red-figure and Kabiric vase-painting see BROMMER 1956, 961. For the Painter of the Dancing Pan see AVRONIDAKI 2008 ; SABETAI 2012, 125-128.

39. Kassel, Hessisches Landesmuseum, Antikensammlung, T 426 ; AVRONIDAKI 2008, 21, pl. 4 : 3-4 ; BAPD 1005143.

40. For the function of rocks in Attic imagery see DIETRICH 2010.

41. The figure of Pan gets multiplied occasionally, as is the case with satyrs. It is possible that the adult Pan on our skyphos is celebrating the upcoming maturation of the young Pan.

42. For Heracles depicted in two age grades see AVRONIDAKI 2012 ; cf. SABETAI 2012, 124-125 (redfigure vases); RITTER 2002, 102-110 (Theban coinage). For scenes with mortals see further AVRONIDAKI 2007, 50, no. 27 ; 103-104, pl. 39.

43. For satyrs in social roles see LISSARRAGUE 2013, 191-215 ; HEINEMANN 2016, 325-425.

44. For the Boeotian Lachkultur in Boeotian red-figure and overpainted wares see SABETAI 2012, 125-129; 132 and SABETAI, AVRONIDAKI 2018, 346-359 respectively.

45. For the rarity of red-figure wares in Boeotian graves and their association with prematurely deceased individuals see SABETAI 2012, 121-122; 132 .

46. See n. 14, above. Some are found also in tombs.

47. For a hornless Pan in examples in Brussels (Fig. 8a-b) and Tübingen see WOLTERS, BRUNS 1940, 102, no. K 34, pl. 32, 5 and 115, no. S 10, pl. 57, 5. For the latter see also BRAUN, HAEVERNICK 1981, 68, no. 418 ; BAPD 1005227.

48. BROMMER 1956, 961 lists seven Kabiric skyphoi depicting Pan ; add PAOLETTI 1998.

49. See BOARDMAN 1997, 925, no. 25, pl. 614. For a satyr among the revelers see WOLTERS, BRUNS 1940, 114, no. S6, pl. 32, 2 Fig. 7. The Tübingen example mentioned in n. 48, above depicts a man wearing a costume and horns in imitation of Pan on the other side, see WOLTERS, BRUNS 1940, pl. 57, 4.

50. For the example in Brussels see n. 48 above. For derisive laughter and caricature in the Kabirion see MITCHELL 2009, 248-279 ; SABETAI, AVRONIDAKI 2018, 356-359.

51. For Pan in cultic activity in rare Attic scenes of the $4^{\text {th }}$ c. BC see ARV 1524, 14 (BAPD 231146 ; Pan and Hermes in sacrifice) ; CVA Berlin 15, pl. 41-42, 1-3 (BAPD 9021753 ; Pan with phiale before altar and herm).

52. PAOLETTI 1998, 323, pl. 89. Pan carries ritual implements (a kanoun and a bowl that may be a phiale) in a scene where a woman and a youth carrying a rooster and a phiale respectively rush 
towards a herm and a louterion (SIEBERT 1990a, pl. 212, no. 131 bis ; BAPD 41966). The image has received little comment but may picture a prenuptial sacrifice. For Pan as overseer of the transition to marriage see SABETAI 2018.

53. See SCHÖNE-DENKINGER 2012 with earlier bibliography.

54. Kabiric skyphos inv. 3286 : ThesCRA II.3.c. (2004) s.v. Initiation, 103, no. 105 (W. Burkert).

55. LEBESSI 1992, 7-8.

56. CVA Thebes 1, pls. 79 and 80, 3 (BAPD 1012709).

57. See, e.g. BAPD $218280 ; 340106 ; 218307 ; 218296$. The L.C. Group was considered Attic by Beazley, but Atticizing Boeotian by recent studies : see CVA Berlin 11, 83-90 (H. Mommsen-A. Schöne-Denkinger) with earlier bibliography.

58. For a unique fragment from the Theban Kadmeia, probably dedicated to the sanctuary of Demeter, see SABETAI, KARAKITSOU 2010-2011, 271.

59. On ritual laughter, in general, see Halliwell 2008, 155-214.

\section{ABSTRACTS}

This paper treats Pan in Boeotia on the basis of the archaeological record. Although often seen as a pastoral god, it is argued that his presence in grottos and in the Kabirion is due to his being an interstitial deity of the wilds and for this reason an overseer of maturation, a marginal period characterised by wildness. Pan appears mostly in terracottas that were found in the Heliconeian cave of the Leibethrian Nymphs and in the Theban Kabirion. Although commonly seen as offerings of shepherds, we may associate them with the status of males who dedicated Pan figurines in anticipation of a safe transition to adulthood, or in thanks for its achievement. Regarding Boeotian painting, one artist juxtaposes a young and a mature Pan on the same vase in order to picture the transformation of the male body when coming of age. Pan is markedly popular in Kabiric art which favoured grotesque figures in comic scenes. His appearance may be looked at through the prism of alterity and ritual laughter that must have been associated with liminality and transitions at this cult place.

Questo articolo è incentrato sul culto di Pan in Beozia, ricostruito sulla base della documentazione archeologica. Benché Pan sia stato spesso studiato come divinità pastorale, tuttavia la sua presenza nelle grotte e nel Kabirion suggerisce una competenza nell'ambito degli spazi liminali e selvaggi, spazi liminali tipicamente connessi processo di maturazione dei giovani. Pan appare soprattutto nelle terrecotte ritrovate nella grotta eliconeiana delle Ninfe Libetrie e nel Kabirion tebano. Benché comunemente interpretate come offerte di pastori, esse possono essere invece considerate dediche di giovani adolescenti che offrivano figurine di Pan per propiziare una transizione sicura verso l'età adulta, oppure per esprimere la propria riconoscenza nei confronti del dio, una volta compiuto il passaggio. Nella ceramica beotica, per esempio, un artista giustappone sullo stesso vaso un Pan giovane e uno maturo, rappresentando così la trasformazione del corpo maschile nel passaggio all'età adulta. Pan è molto popolare nell'arte cabirica che prediligeva figure grottesche nelle scene comiche. Il suo aspetto può essere guardato attraverso il prisma dell'alterità e della risata rituale associati agli spazi liminali e ai riti di passaggio. 
INDEX

Keywords: Pan, Boeotian archaeology, male maturation, vases and terracottas

Parole chiave: Pan, archeologia beota, riti di passaggio maschili, vasi e terrecotte

\section{AUTHOR}

\section{VICTORIA SABETAI}

Research Centre for Antiquity

Academy of Athens

14, Anagnostopoulou street,

GR 10673 Athens, Greece

vsabetai(at)academyofathens.gr 